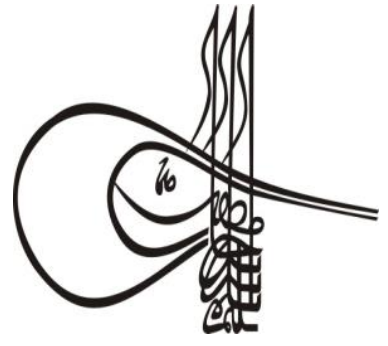

Received/Geliş: 12.10.2019

Gor Report Dates/Rapor Tarihleri: Referee 1 (06.12.2019)-Referee 2 (07.12.2019)

\section{Turkísh Studies Educational Sciences}

Volume 14 Issue 6, 2019, p. 2977-2994

DOI: 10.29228/TurkishStudies.39228

ISSN: 2667-5609

Skopje/MACEDONIA-Ankara/TURKEY
Research Article / Araştırma Makalesi

Article Info/Makale Bilgisi

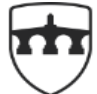

INTERNATIONAL

BALKAN UNIVERSITY

EXCELLENCE FOR THE FUTURE IBU.EDU.MK

\Accepted/Kabul: 20.12 .2019

This article was checked by turnitin.

\title{
ORTAOKUL DÜZEYINDE YABANCI DİL AĞIRLIKLI PROGRAMLARIN DEĞERLENDİRILMESİ
}

\author{
Gülen DAĞISTAN YALÇINKAYA* - Mehmet TAŞDEMIRR**
}

\begin{abstract}
Öz
Yabanc1 dil öğretimi, çağın en önemli eğitim-öğretim politikalarından biri olarak değerlendirilmekte ve Türkiye geçmişten günümüze dek yabancı dil öğretimi konusunda çalışmalar yapmaktadır. Milli Eğitim Bakanlığı (MEB), 2017-2018 eğitim öğretim döneminde belirlenen pilot okullarda ortaokul düzeyinde yabancı dil ağırlıklı program uygulanmasına karar vermiştir. $\mathrm{Bu}$ araştırmada; yabancı dil ağırlıklı programlar, programın uygulayıcısı olan öğretmenler ve programın uygulandığı öğrencilerin velilerinden gelen dönütler doğrultusunda değerlendirilmektedir.

Araştırma sonuçlarına göre, katılımcı öğretmenler, yabancı dil ağırlıklı programlarda yer alan kazanımların öğrencilerin bilişsel ve sosyal gelissim düzeylerine uygun olmadığını ve yabancı dil öğrenimi konusundaki ihtiyaçlarını karşılamadığını ifade etmektedir. İçeriğin öğrenci düzeyinin üzerinde ve çok yoğun olduğunu dile getirmektedir. Ek olarak, programlarda önerilen sürenin yetersiz olduğunu, müfredatı tamamlama çabasındayken, konuşma ve dinleme etkinliklerine yeterince zaman ayrılamadığını belirtmektedir. Değerlendirmenin sonuç odaklı yaklaşımla yapıldığını, portfolyo değerlendirme konusunda da öğrencilerin yetersiz olduğunu ifade etmektedir. Yabancı dil ağırlıklı programların ortaokul düzeyinde uygulanması konusunda görüşlerine başvurulduğunda ise, katılımc1 öğretmenler bu uygulamayı olumlu olarak değerlendirmektedir. Araştırma kapsamında, yabancı dil ağırlıklı sınıflarda eğitim gören öğrencilerin velilerinin de görüşleri alınmakta ve katılımcı veliler programlara ilişkin öğrencilerin yaşadıkları başlıca sorunun, ders sayısının ve İngilizce ders saatinin gereğinden fazla
\end{abstract}

Öğretmen, MEB, E-posta: gulendagistan2008@gmail.com 
olduğunu ifade etmektedir. Öğrenciler İngilizce konuşmada zorluk yaşamakta, isteksiz ve çekingen davranmaktadır. Buna karşın katılımcı veliler, bu programların ortaokul düzeyinde uygulanmasını olumlu bir gelişme olarak değerlendirmektedir.

Anahtar Kelimeler: Yabancı dil ağırlıklı program, Kazanımlar, İçerik, Eğitim Durumları, Değerlendirme

\title{
EVALUATION OF FOREIGN LANGUAGE INTENSIVE CURRICULUMS IN THE SECONDARY SCHOOL LEVEL
}

\begin{abstract}
Foreign language teaching, is regarded as one of the most important education policy of era and Turkey has studied on teaching foreign language from past to present. The Ministry of National Education (MONE) has decided to implement foreign language intensive curriculums at the secondary school level in the pilot schools in 20172018 educational year. In this study, it is aimed to evaluate the foreign language intensive curriculums at the secondary school level in accordance with views of teachers who are implementers of the curriculums and parents of students to whom the curriculums are implemented.

According to the findings, the participant teachers state that functions in the curriculums are not suitable for the students' cognitive and social development levels and do not meet needs of the students in foreign language learning. They express that content is above the students' level and too intense. Prescribed time in the curriculums is insufficient and there isn't enough time for speaking and listening activities. Evaluation is done with result oriented approach. When asked their opinions about implementation of the curriculums at the secondary school level, the teachers consider this implementation as positive. Within the scope of the research, opinions of the parents of the students who are educated in foreign language intensive classes are taken and they state that the main problem experienced by the students is the number of courses about general knowledge and English classes are more than necessary. The students have difficulty in speaking English and are reluctant and timid. On the other hand, the parents consider the implementation at the secondary school level as a positive development.
\end{abstract}

\section{STRUCTURED ABSTRACT}

\section{Introduction}

Foreign language teaching, is regarded as one of the most important education policy of era and Turkey has studied on teaching foreign language from past to present. The Ministry of National Education (MONE) has decided to implement foreign language intensive curriculums at the secondary school level in the pilot schools in 20172018 educational year. The results of this pilot scheme will be evaluated 
and it will be decided whether to continue foreign language teaching with these curriculums.

\section{Research Model}

In this study, it is aimed to evaluate the foreign language intensive curriculums at the secondary school level in accordance with views of teachers who are implementers of the curriculums and parents of students to whom the curriculums are implemented. For this purpose, case study model is used to evaluate the curriculums at the secondary school level. The study group of the research is foreign language teachers working in the secondary schools where the curriculums are implemented and parents of students to whom the curriculums are implemented in Kirşehir province in Turkey.

\section{Analysis of Data}

The data in the research is obtained through interview forms, prepared for teachers and parents, containing structured and semistructured items. Descriptive analysis method is used for data analysis. The data obtained from semi structured items are divided into elements and dimensions or themes and categories according to their characteristics, also relationships between each other are revealed. In the process of creating elements and dimensions, themes and categories three domain experts work independently. In this process, percentage of compliance proposed by Miles and Huberman(1994) is taken into consideration. Percentages of 'Consensus' and 'Dissensus' are calculated and the elements and dimensions, themes and categories with a consensus value of 0.66 are determined. The frequency of repetition of dimensions and categories is determined by the researcher and the frequency values of each of them are shown in tables. The tables are explained and related comments are given. In order to ensure the reliability of the research, original statements of the participants are presented.

\section{Findings and Discussion}

According to the findings; the participant teachers think that functions in the foreign language intensive curriculums are consistent with each other. However, they believe that the functions are not suitable for cognitive and social development levels of the students and do not meet needs of them in foreign language learning.

The teachers state that the most prominent feature of content of the curriculums is flexibility and that they could make changes when necessary. They find the content of the curriculums sufficient to correspond with the functions and do not see any problems. However, they find it insufficient to create an entertaining educational environment and encourage the students to speak English. They relate this situation to the fact that the content is above the students' level and very intense. Also, they mention that it should be supported with songs and fun videos.

The teachers remark that activities, methods and techniques are clearly stated in the curriculums and the activities are made easy to understand by exemplifying them. In addition, they express a positive opinion that the activities and methods-techniques are appropriate to the functions and content and that they are formed by considering

\section{Turkish Studies - Educational Sciences}

Volume 14 Issue 6, 2019 
learning characteristics of the students. Moreover, they believe that the activities provide active participation and that the methods and techniques are appropriate to structure of English course. But when it comes to prescribed time, the curriculums are inadequate and there are problems. The teachers state that in an effort to complete the given curriculum, they could not devote enough time to speaking and listening activities.

The teachers express that assessment and evaluation techniques are determined by taking into consideration developmental level of the students in foreign language learning and that these techniques are appropriate to structure of English course. However, the functions could be assessed and evaluated with the activities in the curriculums but definitely insufficient. They also state that assessment activities are determined with a result-oriented approach, that if the student passes the exam, he / she is considered as successful and they do not evaluate the students in the process. When it comes to portfolio assessment, the students are unable to prepare their own portfolio files.

It is a common view among the teachers that the curriculums are too intense and the time is insufficient so that there is not enough time for speaking and listening activities. They also state that the curriculums are inadequate to meet needs of the students in foreign language learning and in this case what is learned is superficial. The teachers also think that the students are reluctant to speak English and the curriculums could not be implemented effectively and efficiently due to lack of materials and sources, and so their motivation is affected adversely. The teachers express a positive opinion about implementation of the curriculums at the secondary school level and state that the things learned at an early age would be more permanent.

The participant parents opine that the main problem the students have with regard to the curriculums is excessive number of courses and the courses about general knowledge continue with the same importance and so the students cannot devote sufficient time to English. In addition, they state that the students are bored of this intensity due to high number of English classes. One of the most important problems the parents highlight is that students have difficulty in speaking English. They mention that the students are reluctant and hesitant in speaking English and the curriculums are inadequate in this regard. A small part of the parents who participated in the research express that due to too much homework and difficult source book, the students are demotivated.

Concerning implementation of the curriculums at the secondary school level, the parents regard it positively and suggest that a foreign language could be learned more easily at an early age and language learning becomes difficult at later ages.

Keywords: Foreign language intensive curriculum, Functions, Content, Language tasks and study skills, Evaluation

\section{Giriş}

Son yıllarda dünyada hızlı bir küreselleşme süreci yaşanmakta ve bu süreç dünyanın küçülmesini, ülkeler arası mesafelerin kısalmasını ve bireylerin birbirlerine daha da yakınlaşmasını 
sağlamaktadır. Yaşanan bu gelişmelerle birlikte, ülkeler ve bireylerarası etkileşim artmakta, iletişim olanakları ön plana çıkmaktadır.

Daha önceden toplumlar arası iletişim genellikle herhangi bir toplum adına devlet düzeyinde gerçekleşiyorken; günümüzde iletişim, kamusal kuruluşların yanında özel olarak da kurumsal ya da bireysel girişimlerle gerçekleşebilmektedir. Özellikle iletişim teknolojisinin gelişmesiyle bu süreç ivme kazandığg gibi, kültürlerarası etkileşim ve buna bağlı olarak da kültürlerarası iletişim her alanda yaygınlaşıp sınırlarını oldukça zorlamış bulunmaktadır. Bu etkileşim sonucunda insanlar farklı kültürler hakkında sadece bilgi sahibi olmak istemekten öte; hissettikleri ihtiyacı gidermek doğrultusunda birbirlerinin dillerini öğrenmeye yönelmişlerdir (Sertdemir, 2013). Dünyada yaşanan tüm gelişmelerle birlikte artan toplumlararası iletişim ihtiyacı, bireylerin sadece anadilleri ile iletişim kurmalarının, sınırlar ötesine ulaşmada yetersiz kalmasına neden olmuş ve bu durum farklı dilleri öğrenme ihtiyacını beraberinde getirmiştir.

Dil, ülkelerin ve bireylerin birbirleri ile çok yönlü iletişim kurma sürecinde bir araç olarak kullanılmaktadır. Hayatımızın her alanında yer alan dilin, hızla değişen ve kendini yenileyen dünya değerler sistemi içinde her alanda bilgi alışverişi yapabilmek, bireyler ve toplumlar arası ilişkileri yürütebilmek ve kendimizi ifade edebilmek için her kapıyı açan bir anahtar olduğu söylenebilir (Tarakcioğlu, 2012).

Ferdinand de Saussure, dil yetisinin bütün insanlarda var olan ortak bir özellik olduğu görüşündedir (Akerson, 2008). Ortner ise, konuşmanın insanların doğuştan beraberinde getirdiği bir yeti olduğunu ve her insanın evrensel bir dilbilgisine sahip olduğunu belirtmektedir. (Pöhnl, 2010).

Farklı dilleri öğrenme ihtiyacı, yabancı dil öğrenimi ve öğretimi konusunu gündeme getirmiştir. Çağa ayak uydurmaya çalışan Türkiye'de de yabancı dil öğretimi üzerinde önemle durulan ve güncelliğini asla kaybetmeyen bir konudur. İlkokul ikinci sınıftan itibaren zorunlu ders olarak karşımıza çıkan yabancı dil dersi bütün öğretim kurumlarında ve kademelerinde yer almaktadır.

Başkan (2006), yabancı dili, bir ülkede veya toplumda geçerli anadil dışındaki tüm dilleri kapsayan dil olarak tanımlarken, Oğuzkan (1993) ise, yetişkin insanların olduğu gibi öğrencilerin de akademik, toplumsal ve mesleki alanlarda gelişimlerine katkıda bulunmak amacıyla anadil dışında öğretilen dil olarak tanımlamıştır.

Bir yabancı dile gerçekten hâkim olabilmek; o dilde okuyup anlamayı, konuşmayı ve yazabilmeyi gerektirir. Bu da, kişinin anadilini öğrenirken sahip olduğu doğal konuşma ortamına sahip olmayışı nedeniyle düzenli ve sistemli bir eğitim ve öğretimi zorunlu kılar. Zira kişinin anadilini konuşmayı öğrenirken sahip olduğu dile ait çeşitli örnekleri sürekli olarak işletebilme firsatı, bir yabanc1 dil için her zaman söz konusu değildir (Kuzu, 2013).

Yabanc1 dil öğretimi, çağın en önemli eğitim-öğretim politikalarından biri olarak değerlendirilebilir. Türkiye'de geçmişten günümüze dek çağın gereklerini yerine getirmeye çalışmakta ve yabancı dil öğretimine azımsanamayacak oranda kaynak ayırmaktadır. Ancak uzun yıllardır ciddi emek verilen ve güncelliğini hiç yitirmeyen yabancı dil öğretiminde hedeflenen düzeyde kazanım sağlanamamakta ve istenilen verim alınamamaktadır.

2013 yılında Türkiye'deki devlet okullarında İngilizce dilinin öğretimine ilişkin yapılan ulusal ihtiyaç analizinde gözlemlenen öğretmenlerin tamamı İngilizceyi, dünya genelindeki birçok dil akademisyeninin önerdiği gibi, bir iletişim dili olarak değil, bir "ders konusu" olarak öğretmektedir. Örneğin, öğrenciler:

- Söyledikleri şeyin anlamına kafa yormaksızın öğretmenin sorularını İngilizce nasıl cevaplayacaklarını ve kendi iletişim gereksinimleri için dili nasıl kullanabileceklerini;

\section{Turkish Studies - Educational Sciences}

Volume 14 Issue 6, 2019 
- Bir kitaptaki metni, metnin anlamını ya da kendi hayatlarına olan faydasını kavramaya gerek duymaksızın yüksek sesle okumay1;

- Aynı gramer yapısını en temel kişisel bilgileri aktarmak için bile kullanmayı becermeksizin, gramer tabanlı bir testte doğru cevabı seçmeyi öğrenmektedirler (TEPAV \& British Council, 2013).

Gerek eğitim sisteminden, gerekse program esaslarından kaynaklanan yanlışlıklardan dolayı beklenen yararın sağlanamaması ve öğrencilere kalıcı bir yabancı dilin öğretilememesi, Türkiye'nin bir gerçeği olarak değerlendirilmektedir (Bağçeci, 2004).

Ruck (1992), erken yaşta yabancı dil öğrenmenin zihinsel ve ruhsal gelişim açısından önemli etkileri olduğunu ve çocukta temel sosyal yeterliliklerin gelişimine katkı sağladığını ifade etmektedir. Bunun yanı sıra, yabancı dil öğretiminin hedeflerinden birisinin de bireyin farklı yaşam tarzlarına ve kültürlere açık bir kişilik geliştirmesini sağlamak olduğunu vurgulamaktadır.

Yabancı dil öğretiminde yaşanan sorunların üstesinden gelmek adına; 1990'lı yıllarda belirli liselerde uygulanan ancak daha sonra rafa kalkan yabancı dil hazırlık sınıfi, bu kez daha erken yaşta uygulanmak üzere, ortaokul düzeyinde yabancı dil ağırlıklı sınıflar olarak gündeme gelmiştir. Milli Eğitim Bakanlığı (MEB), 2017-2018 eğitim öğretim döneminde 81 ilde belirlenen pilot okullarda ortaokul düzeyinde yabancı dil ağırlıklı program uygulanmasına karar vermiştir (MEB, 2017).

$\mathrm{Bu}$ pilot uygulamanın sonuçları değerlendirilecek ve bu programlarla yabancı dil öğretimine devam edilip edilmeyeceğine karar verilecektir. $\mathrm{Bu}$ amaçla programların ne derece etkili ve verimli olduğunun değerlendirilmesi gerekmektedir. Bu araştırmada; yabancı dil ağırlıklı programlar öğeleri(kazanımlar, içerik, eğitim durumu, değerlendirme) açısından, programın uygulayıcısı olan öğretmenler ve programın uygulandığı öğrencilerin velilerinden gelen dönütler doğrultusunda değerlendirilecektir.

\section{Araştırmanın Amacı}

$\mathrm{Bu}$ çalışmada; ortaokul düzeyinde yabancı dil ağırlıklı programların, programların uygulayıcısı olan öğretmenlerin ve programların uygulandığı öğrencilerin velilerinin görüşleri doğrultusunda değerlendirilmesi amaçlanmıştır.

$\mathrm{Bu}$ amaçla şu sorulara cevap aranmıştır:

1. Yabancı dil ağırlıklı programların kazanımlar öğesine ilişkin öğretmenlerin görüşleri nelerdir?

2. Yabancı dil ağırlıklı programların içerik öğesine ilişkin öğretmenlerin görüşleri nelerdir?

3. Yabancı dil ağırlıklı programların eğitim durumları öğesine ilişkin öğretmenlerin görüşleri nelerdir?

4. Yabancı dil ağırlıklı programların değerlendirme öğesine ilişkin öğretmenlerin görüşleri nelerdir?

5. Yabancı dil ağırlıklı sınıflarda yaşanan sorunlara ilişkin öğretmenlerin görüşleri nelerdir?

6. Yabancı dil ağırlıklı programların ortaokul düzeyinde uygulanmasına ilişkin öğretmenlerin görüşleri nelerdir?

7. Yabancı dil ağırlıklı sınıflarda yaşanan sorunlara ilişkin velilerin görüşleri nelerdir?

8. Yabancı dil ağırlıklı programların ortaokul düzeyinde uygulanmasına ilişkin velilerin görüşleri nelerdir? 


\section{Yöntem}

\section{Araştırma Modeli}

Araştırmada, ortaokul düzeyinde yabancı dil ağırlıklı programların değerlendirilmesi amacıyla durum çalışması modelinden yararlanılmıştır. Durum çalışmasında amaç, belirli bir durumun derinlemesine incelenerek, detaylı sonuçların ortaya çıkarılmasıdır. Nitel araştırmadaki durum çalışmasında, duruma yönelik etkenler, durumun başka duruma etkisi, durumu ortaya çıkaran etkenler vb. bir bütün olarak incelenir (Köse, 2013).

\section{Çalıșma Grubu}

Araştırmanın çalışma grubunu; Kırşehir ilinde, yabancı dil ağırlıklı programların uygulandığı ortaokullarda görev yapan yabancı dil öğretmenleri ve yabanc1 dil ağırlıklı programların uygulandığı öğrencilerin velileri oluşturmaktadır.

\section{Veri Toplama Aracı}

Araştırmada veriler; öğretmenler ve veliler için hazırlanan, yapılandırılmış ve yarı yapılandırılmış maddeler içeren görüşme formları ile elde edilmiştir. Öğretmen görüşme formunda kişisel bilgileri içeren(cinsiyet ve mesleki kıdem) yapılandırılmış 2 madde, ve yarı yapılandırılmış 6 madde; veli görüşme formunda ise kişisel bilgiler içeren(cinsiyet) yapılandırılmış 1 madde ve yarı yapılandırılmış 2 madde yer almaktadır.

Görüşme formlarında yer alan yarı yapılandırılmış maddeler literatür taramasına dayalı olarak hazırlanmış olup, kapsam geçerliliği ile ilgili olarak dört yabancı dil öğretmeni ile ön görüşme sağlanmıştır. Yapılan ön görüşmenin ardından gerekli düzenlemeler yapılmış ve formlar dört program geliştirme uzmanı tarafindan incelenmiştir. Gelen dönütler çerçevesinde formlara son hali verilmiştir. Görüşme formlarında yer alan yarı yapılandırılmış maddeler şunlardır:

\section{Öğretmen Görüşme Formu}

1. Yabancı dil ağırlıklı programların kazanımlar öğesine ilişkin görüşleriniz nelerdir?

2. Yabancı dil ağırlıklı programların içerik öğesine ilișkin görüşleriniz nelerdir?

3. Yabancı dil ağırlıklı programların eğitim durumları öğesine ilişkin görüşleriniz nelerdir?

4. Yabancı dil ağırlıklı programların değerlendirme öğesine ilişkin görüşleriniz nelerdir?

5. Yabancı dil ağıllıklı sınıflarda yaşanan sorunlara ilişkin görüşleriniz nelerdir?

6. Yabancı dil ağırlıklı programların ortaokul düzeyinde uygulanmasına ilişkin görüşleriniz nelerdir?

\section{Veli Görüşme Formu}

1. Yabancı dil ağırlıklı sınıflarda yaşanan sorunlara ilişkin görüşleriniz nelerdir?

2. Yabancı dil ağırlıklı programların ortaokul düzeyinde uygulanmasına ilişkin görüşleriniz nelerdir?

\section{Verilerin Analizi}

Verilerin analizi için betimsel analiz yönteminden faydalanılmıştır. Öncelikle öğretmenlerin görüşlerini içeren formlar, öğretmen formu no(Ö1, Ö2, Ö3 ...), cinsiyet $(\mathrm{kad} ı n(\mathrm{~K})$ veya erkek(E)) ve mesleki kıdem(10 yıl altı(10-), 10 yıl üstü(10+)) şeklinde; velilerin görüşlerini içeren formlar ise veli formu no(V1, V2, V3...) ve cinsiyet $(\operatorname{kad} ı n(K)$ veya erkek(E)) şeklinde kodlanmıştır. Yarı yapılandırılmış maddelerden elde edilen veriler özelliklerine göre öğe ve boyutlara ya da tema ve kategorilere ayrılarak birbirleri arasındaki ilişkiler ortaya konmuştur. Öğe ve boyutların, tema ve kategorilerin oluşturulması aşamasında, 3 farklı alan uzmanı birbirinden bağımsız olarak çalışmıştır. Daha sonra bir araya gelinmiş ve bağımsız olarak oluşturulan öğe ve boyutlardan, tema ve kodlardan üzerinde ortak karara varılanlar belirlenmiştir. Bu süreçte Miles ve

\section{Turkish Studies - Educational Sciences}

Volume 14 Issue 6, 2019 
Huberman (1994) tarafindan önerilen uyum yüzdesi dikkate alınmıştır. 'Görüş birliği', 'Görüş ayrıllğı’ yüzdeleri hesaplanarak 0,66 oranında görüş birliği değeri sağlanan öğe ve boyutlar, tema ve kodlar tespit edilmiştir. Elde edilen verilerden boyutların ve kategorilerin tekrarlanma sıklıkları araştırmacı tarafindan belirlenmiş ve her birinin frekans değerleri tablolarla gösterilmiştir. Tablolar açılanmış ve ilgili yorumlara yer verilmiştir. Araştırmanın güvenirliğinin sağlanması için ise, katılımcıların sorulara ilişkin orijinal ifadeleri sunulmuştur.

\title{
Bulgular
}

\section{Yabancı Dil Ağırlıkı Programların Kazanımlar Öğesine İliş̧in Katılımcı Öğretmen Görüşleri}

Yabancı dil ağırlıklı programların kazanımlar öğesine dair katılımeı öğretmen görüşleri analiz edilmiş, 1 öğe ve 3 boyut oluşturulmuştur. Elde edilen öğe ve boyutlar Tablo 1'de verilmektedir.

Tablo 1: Yabancı Dil Ağırlıklı Programların Kazanımlar Öğesine İlişkin Katılımcı Öğretmen Görüşleri

\begin{tabular}{cccc}
\hline \multirow{2}{*}{ Öğe } & Boyut & \multicolumn{2}{c}{$f$} \\
\cline { 3 - 4 } Kazanımlar & Tutarlılık & 8 & 2 \\
& Gelişim Düzeyine Uygunluk & 3 & 8 \\
& İhtiyaçları Karşıllama & 3 & 9 \\
\hline
\end{tabular}

Tablo 1'e göre, yabancı dil ağırlıklı programların kazanımlar öğesini; 'tutarlılık' boyutunda katılımc1 öğretmenlerin 8'i, 'gelişim düzeyine uygunluk' boyutunda 3'ü, 'ihtiyaçları karşılama' boyutunda ise 3'ü yeterli bulmaktadır. Buna karşılık, 'tutarlılık' boyutunda katılımcı öğretmenlerin 2'si, 'gelişim düzeyine uygunluk' boyutunda 8'i, 'ihtiyaçları karşılama' boyutunda ise 9'u yetersiz olarak görmektedir.

Katılımcı öğretmenler, yabancı dil ağırlıklı programlarda yer alan kazanımların birbirleriyle tutarlı olduğu görüşündedir. Buna karşın kazanımların, öğrencilerin bilişsel ve sosyal gelişim düzeylerine uygun olmadığını ve yabancı dil öğrenimi konusundaki ihtiyaçlarını karşılamadığını düşünmektedir. Yabancı dil ağırlıklı programların kazanımlar öğesine ilişkin katılımcı öğretmen orijinal görüş örnekleri aşağıda verilmiştir:

\begin{abstract}
"Yabancı dil ağırlıklı programda yer alan kazanımlar birbirleriyle tutarlı. Öğrenciye kazanımlar veriliyor, örneklendirilip pekiştiriliyor. Yalnız kazanımlar öğrencilerin zihinsel ve sosyal gelişim düzeylerinin üstünde. Bu kadarı bu yaş grubu için ağır. Ayrıca kazanımlar öğrencilerin yabancı dil öğrenimi konusundaki ihtiyaçlarını da karşılamıyor."(6ÖK10-)

"Programda kazanımlar ileriki öğrenmeleri kolaylaştırıcı ve ilgi çekici şekilde belirlenmiş yani ihtiyaca ve öğrenci seviyesine uygun denilebilir. Kazanımlar birbirleriyle de tutarlı. Birbirinin üzerine inşa edilerek ilerliyor. Basitten zora doğru ilerleyen doğru bir örgüde verilmiş. Fakat daha otantik ve hayatın içinden örnek ve kazanımlarla desteklenmesi ve üretken becerilere ağırlık verilmesi iyi olur.”(3ÖE10-)
\end{abstract}

\section{Yabancı Dil Ağırıkıı Programların İçerik Öğesine İlişkin Katılımcı Öğretmen Görüşleri}

Yabancı dil ağırlıklı programların içerik öğesine ilişkin katılımcı öğretmen görüşleri analiz edilmiş, 1 öğe ve 6 boyut ortaya çıkmıştır. Elde edilen öğe ve boyutlar Tablo 2'de sunulmaktadır. 
Tablo 2: Yabancı Dil Ağırlıklı Programların İçerik Öğesine İlişkin Katılımcı Öğretmen Görüşleri

\begin{tabular}{cccc}
\hline & & \multicolumn{2}{c}{$\boldsymbol{f}$} \\
\cline { 3 - 4 } Öğe & Boyut & Yeterli & Yetersiz \\
\hline \multirow{4}{*}{ Esneklik } & 12 & - \\
& Kazanımimlarla Örtüşme & 7 & 4 \\
& Eğlenceli Eğitim Ortamı & 4 & 7 \\
& Konuşmaya Cesaretlendirme & 3 & 9 \\
& Düzeye Uygunluk & 3 & 8 \\
& Yoğunluk & 2 & 10 \\
\hline
\end{tabular}

Tablo 2 incelendiğinde, yabancı dil ağırlıklı programların içerik öğesini; 'esneklik' boyutunda katılımc1 öğretmenlerin 12'si, 'kazanımlarla örtüşme' boyutunda 7'si, 'eğlenceli eğitim ortamı' boyutunda 4'ü, 'konuşmaya cesaretlendirme' boyutunda 3'ü, 'düzeye uygunluk' boyutunda 3'ü, 'yoğunluk' boyutunda ise 2'si yeterli bulmaktadır. Öte yandan, 'esneklik' boyutunda katılıme1 öğretmenlerin hiçbiri yetersiz görmemekte, 'kazanımlarla örtüşme' boyutunda 4'ü, 'eğlenceli eğitim ortamı' boyutunda 7'si, 'konuşmaya cesaretlendirme' boyutunda 9'u, 'düzeye uygunluk' boyutunda 8'i, 'yoğunluk' boyutunda ise 10'u yetersiz olarak değerlendirmektedir.

Katılımcı öğretmenler, yabancı dil ağırlıklı programların içerik öğesine ilişkin en belirgin özelliğin esneklik olduğunu, gereken durumlarda değişiklikler yapabildiklerini ifade etmektedir. Kazanımlarla örtüşmesi konusunda programların içeriğini yeterli bulmakta, herhangi bir sıkıntı görmemektedir. Ancak eğlenceli bir eğitim ortamı oluşturmada ve öğrenciyi İngilizce konuşmaya cesaretlendirme konusunda içeriği yetersiz bulmaktadır. Bu durumu, içeriğin öğrenci düzeyinin üzerinde ve çok yoğun olması ile ilişkilendirmekte, özellikle şarkı ve eğlenceli videolarla programların desteklenmesi gerektiğini dile getirmektedir. Yabancı dil ağırlıklı programların içerik öğesine ilişkin katılımcı öğretmen orijinal görüş örnekleri aşağıda verilmiştir:

"Kazanımlarla içeriğin örtüştüğünü düşünmüyorum. Ders saati de içeriğe uygun değil, fazla yoğun. Üstelik öğrenci seviyesinin çok çok üzerinde. Öğrenciye aşırı yükleme yapmış oluyoruz. Program öğrenciyi İngilizce konuşmaya cesaretlendirici nitelikte değil, eğlenceli bir eğitim ortamı oluşturmada eksik kalmakta. Ancak programda esneklik payı var, konular arası geçişler ve eklemeler yapılabilir."(7ÖK10-)

"İçerik ve kazanımlar birbirleriyle örtüşmektedir. İçerik öğrenci düzeyine de uygun fakat aşırı yoğun. Bu yoğunluk azaltılabilir ve daha güncel olabilir. Bu içerikle öğrenciye konuşma becerisi kazandırmak zor. İstek ve ihtiyaç karşılamak için ise konuşmak önemli. Öğrenciye eğlenceli bir eğitim ortamı sunmuyor. Öğrencilerin günlük hayattaki ihtiyaçlarının karşılanması gerekir Ama bunu gerektiği durumlarda biz yapıyoruz. İçeriğin dışına da çıkabiliyoruz tabii ki.”(1ÖK10-)

\section{Yabancı Dil Ağırıkı Programların Eğitim Durumları Öğesine İlişsin Katılımcı Öğretmen Görüşleri}

Yabancı dil ağırlıklı programların eğitim durumları öğesine ilişkin katılımcı öğretmen görüşleri analiz edilmiş, 1 öğe ve 6 boyut belirlenmiştir. Elde edilen öğe ve boyutlar Tablo 3'de yer almaktadir.

Turkish Studies - Educational Sciences

Volume 14 Issue 6, 2019 
Tablo 3: Yabancı Dil Ağırlıklı Programların Eğitim Durumları Öğesine İlişkin Katılımcı

\begin{tabular}{llcc} 
& \multicolumn{1}{c}{ Öğretmen Görüşleri } & \multicolumn{2}{c}{$\boldsymbol{f}$} \\
\cline { 3 - 4 } Ö̆ğe & Boyut & Yeterli & Yetersiz \\
\hline \multirow{4}{*}{ Eçıklık } & 12 & - \\
Durumları & Kazanımlara ve İçeriğe Uygunluk & 1 & - \\
& Öğrenme Özelliklerini Dikkate Alma & 10 & 2 \\
& Aktif Katıllımı Sağlama & 9 & 2 \\
& Dersin Yapısına Uygunluk & 7 & 5 \\
& Süre & 3 & 9 \\
\hline
\end{tabular}

Tablo 3'e göre, yabancı dil ağırlıklı programların eğitim durumları öğesini; 'açıklık' boyutunda katılıme1 öğretmenlerin 12'si, 'kazanımlara ve içeriğe uygunluk' boyutunda 10'u, 'öğrenme özelliklerini dikkate alma' boyutunda 10'u, 'aktif katılımı sağlama' boyutunda 9'u, 'dersin yapısına uygunluk' boyutunda 7'si, 'süre' boyutunda ise 3'ü yeterli görmektedir. Diğer yandan, 'açıklık' ve 'öğrenme özelliklerini dikkate alma' boyutunda katılımcı öğretmenlerin hiçbiri yetersiz bulmamakta, 'kazanımlara ve içeriğe uygunluk' boyutunda 1'i, 'aktif katılımı sağlama' boyutunda 2'si, 'dersin yapısına uygunluk' boyutunda 5'i, 'süre' boyutunda ise 9'u, yetersiz olarak değerlendirmektedir.

Görüşlerine başvurulan katılımcı öğretmenler programlarda etkinliklerin, yöntem ve tekniklerin açık ve net bir şekilde belirtildiğini, etkinliklerin örneklendirilerek kolay anlaşılır hale getirildiğini ifade etmektedir. Ayrıca etkinliklerin ve belirtilen yöntem-tekniklerin kazanımlara ve içeriğe uygunluğu ve öğrencilerin öğrenme özellikleri dikkate alınarak oluşturulduğu konusunda olumlu görüş belirtmektedir. Üstelik etkinliklerin aktif katılımı sağladığı ve yöntem-tekniklerin İngilizce dersinin yapısına uygun olduğu görüşündedir. Yalnız süre söz konusu olduğunda, ögretmenler arasında programların bu konuda yetersiz olduğu ve sıkıntı yaşandığı görüşü yaygındır. Verilen müfredatı tamamlama çabasındayken, konuşma ve dinleme etkinliklerine yeterince zaman ayıramadıklarını ifade etmektedir. Yabancı dil ağırlıklı programların eğitim durumları öğesine ilişkin katılımcı öğretmen orijinal görüş örnekleri aşağıda verilmiştir:

"Programda etkinlikler açık bir şekilde ifade edilmiş. Etkinlikler örneklendirilerek daha kolay anlaşılır hale getirilmiş. Yani etkinliklerin yöntem ve tekniklerin kazanımlara ve dersin içeriğine yeterli derecede uygun olduğu söylenebilir. İçeriğe de uygun aslında. Öğrencilerin öğrenme özellikleri de dikkate alınarak seçilmiş. Eğlenceli hale getirilerek ders için sunulmuş. Öğrencilerin derse aktif şekilde katılmasını sağlayacak nitelikte. Öğrencilerin hepsi de derse aktif katıllyor. Bunu program sağlıyor açıkçası. Programda önerilen araç gereç ve materyaller dersin anlaşılması için yeterince uygun. Dil söz konusu olduğu için fazla materyal ihtiyacımız da yok. Açıkçası en önemli sorunun süre olduğu söylenebilir. Bu açıdan çok sıkıntı yaşıyoruz."(5ÖE10+)

"Etkinlikler, yöntem ve teknikler açık ve net bir şekilde belirlenmiş ve dersin içeriğine uygun. Sadece öğrenciler öğrenmeyi ihtiyaç olarak görmeli. Yalnız öğrencilerin öğrenme özellikleri dikkate alınmamış. Çünkü her bölgenin ve her okulun farklı ihtiyaçları olduğunu düşünüyorum. Eski programlara göre öğrenciler derse daha aktif bir şekilde katıllyor. Bu net bir şekilde fark ediliyor. Okuldaki ve programdaki araç ve gereçlerin daha da geliştirilmesi gerekmekte. Programda önerilen sürede kesinlikle yetersiz. Müfredat yetiştirmek için konuşma ve dinleme gibi etkinlikler yapamıoruz."(1ÖK10-) 


\section{Yabancı Dil Ağırıklı Programların Değerlendirme Öğesine İlişskin Katılımeı Öğretmen Görüsşleri}

Yabancı dil ağırlıklı programların değerlendirme öğesine ilişkin katılımcı öğretmen görüşlerinin analiz edilmesi neticesinde, 1 öğe ve 5 boyut oluşturulmuştur. Elde edilen öğe ve boyutlar Tablo 4'de sunulmaktadır.

Tablo 4: Yabancı Dil Ağırlıklı Programların Değerlendirme Öğesine İlişkin Katılımcı Öğretmen Görüşleri

\begin{tabular}{cccc}
\hline \multirow{2}{*}{ Öğe } & Boyut & \multicolumn{2}{c}{$\boldsymbol{f}$} \\
\cline { 3 - 4 } & Yeterli & Yetersiz \\
\hline \multirow{4}{*}{ Değerlendirme } & Gelişim Düzeyine Uygunluk & 7 & 4 \\
& Dersin Yapisina Uygunluk & 7 & 2 \\
& Kazanımlara Uygunluk & 4 & 8 \\
& Süreç Temelli Yaklaşım & - & 12 \\
& Portfolyo Düzenleyebilme & - & 11 \\
\hline
\end{tabular}

Tablo 4 incelendiğinde, yabancı dil ağırlıklı programların değerlendirme öğesini; 'gelişim düzeyine uygunluk' ve 'dersin yapısına uygunluk' boyutunda katılımcı öğretmenlerin 7'si, 'kazanımlara uygunluk' boyutunda 4'ü yeterli görmekteyken; 'süreç temelli yaklaşım' ve 'portfolyo düzenleyebilme' boyutunda ise hiçbiri yeterli görmemektedir. Buna karşıllk, 'gelişim düzeyine uygunluk' boyutunda katılımcı öğretmenlerin 4'ü, 'dersin yapısına uygunluk' boyutunda 2'si, 'kazanımlara uygunluk' boyutunda 8'i, 'süreç temelli yaklaşım' boyutunda 12'si, 'portfolyo düzenleyebilme' boyutunda ise 11 ' $\mathrm{i}$, yetersiz bulmaktadır.

Katılımcı öğretmenler, programların değerlendirme boyutuna ilişkin ölçme değerlendirme tekniklerinin öğrencilerin yabancı dil öğrenmedeki gelişim düzeyleri dikkate alınarak belirlendiği ve bu tekniklerin İngilizce dersinin yapısına uygun olduğu yönünde görüş belirtmektedir. Ancak ölçme değerlendirme etkinlikleri ile programlarda yer alan kazanımların ölçülebilir fakat kesinlikle yetersiz olduğunu ifade etmektedir. Ayrıca değerlendirme etkinliklerinin sonuç odaklı yaklaşımla belirlendiğini, sınavı geçerse öğrencinin başarılı kabul edildiğini ve süreçte öğrenciyi değerlendirmediklerini belirtmektedir. Portfolyo değerlendirme söz konusu olduğunda da, öğretmenler arasında öğrencilerin kendi gelişim dosyalarını düzenleyebilmekte yetersiz oldukları görüşü yaygındır. Yabancı dil ağırlıklı programların değerlendirme öğesine ilişkin katılımcı öğretmen orijinal görüş örnekleri aşağıda verilmiştir:

"Programda önerilen ölçme değerlendirme teknikleri kazanımları ölçmeye uygun olarak belirlenmiş fakat bazı kazanımlar için bunu söyleyemeyiz. İşlediğimiz bazı konuları ölçmeye yer veriyor ama bazıları için yer vermemiş. Öğretmen olarak ben ekliyorum. Öğrencilerin konuşma becerilerini ölçmede gelişim düzeyleri dikkate alınmış fakat dilbilgisi olarak yetersiz kalmış. Dilbilgisini destekleyen yeteri kadar ölçme değerlendirme etkinliği yok. Sadece pratikte kalmış. Etkinlikler tam olarak dersin yapısına uygun belirlenmemiş. Konudan konuya değişiklik gösteriyor. Bazı konuları işliyoruz fakat etkinlik ve ölçme değerlendirme sorusu az ya da hiç yok. Sürece dönük bir değerlendirme de yapmıyoruz. Konu bitiminde sınav yapıp öğrenilip öğrenilmediğine bakıyoruz. Öğrenciler kendi gelişim dosyalarını düzenleyemiyor. Aslında düzenleyebilseler süreç değerlendirmesi kolaylaşır."(8ÖE10+)

"Programdaki ölçme değerlendirme etkinlikleri ile verilen kazanımlar ölçülebilir ama kesinlikle yetersiz. Daha fazla olmalı. Öğrencilerin gelişimleri açısından da eksik buluyorum. Sınava dayalı bir dil öğrenimi için yeterli olabilir ama konuşma için kesinlikle eksik. Sonuç odaklı değerlendirme yapıyoruz. Konu bitiminde öğrenci sınavı

Turkish Studies - Educational Sciences

Volume 14 Issue 6, 2019 
geçerse doğru bir program olarak algılanmakta. Öğrenciler etkinlikleri gayet iyi yapıyorlar ama kendi dosyalarını düzenlemekte yetersizler."(9ÖK10-)

\section{Yabancı Dil Ağırlıklı Sınıflarda Yaşanan Sorunlara İlişkin Katılımeı Öğretmen Görüşleri}

Yabancı dil ağırlıklı sınıflarda yaşanan sorunlara ilişkin katılımcı öğretmen görüşleri analiz edilmiş, 1 tema ve 6 kategori oluşturulmuştur. Elde edilen tema ve kategoriler Tablo 5 'te verilmektedir.

Tablo 5: Yabancı Dil Ağırlıklı Sınıflarda Yaşanan Sorunlara İlişkin Katılımcı Öğretmen Görüşleri

\begin{tabular}{ccc}
\hline Tema & Kategori & $\boldsymbol{f}$ \\
\hline & Yetersiz Süre & 12 \\
Yağun Program & 11 \\
Sinıncl Dil Ağırlıkılı Yaşanan & İhtiyacın Karşılanamaması & 10 \\
Sorunlar & İngilizce Konuşmada İsteksizlik & 10 \\
& Materyal ve Kaynak Eksikliği & 7 \\
& Kelime Öğretiminde Yaşanan Zorluklar & 6 \\
\hline
\end{tabular}

Tablo 5'e bakıldığında, yabancı dil ağılıklı sınıflarda yaşanan sorunlar konusunda; katılımcı öğretmenlerin 12'si 'yetersiz süre' kategorisinde, 11'i 'yoğun program' kategorisinde, 10'u 'ihtiyacın karşılanamaması' ve 'İngilizce konuşmada isteksizlik' kategorisinde, 7'si 'materyal ve kaynak eksikliği' kategorisinde, 6's1 ise 'kelime öğretiminde yaşanan zorluklar' kategorisinde görüş bildirmişlerdir.

Katılımcı öğretmenler, programlara ilişkin yaşadıkları en büyük sorunun yetersiz süre ve yoğun program olduğu konusunda hemfikirdir. Program yoğun, süre yetersiz olduğu için konuşma ve dinleme etkinliklerine yeterince zaman ayrılamadığı görüşü yaygındır. Öğrencilerin yabancı dil öğrenimi konusundaki ihtiyaçlarını karşılamak noktasında da programın yetersiz olduğunu ve bu durumda öğrenilenlerin yüzeysel kaldığını ifade etmektedir. Ayrıca öğretmenler, öğrencilerin İngilizce konuşmak konusunda isteksiz davrandığ programın etkili ve verimli şekilde uygulanamadığ 1 ve motivasyonlarının olumsuz etkilendiği görüşündedir. Programda öğrenilmesi gereken kelimelerin oldukça yoğun olması nedeniyle öğretmenler kelime öğretiminde zorluklar yaşamakta, öğrenciler de bu konuda isteksiz davranmaktadır. Yabancı dil ağırlıklı sınıflarda yaşanan sorunlara ilişkin katılımcı öğretmen orijinal görüş örnekleri aşağıda verilmiş̧ir:

"Süre ve içeriğin uyuşmaması en büyük sorunumuz. Karşımızda çok yoğun bir program var. Tekrar yapamıoruz. Konuşma ve dinleme etkinliklerine yeterince zaman ayıramıyoruz. Bu yoğunluktan öğrenciler de sıkılıyor ve ihtiyaçları karşılanmıyor doğal olarak. Materyal ve kaynak eksikliği de motivasyon düşürüyor. Öğrenciler hedef dili konuşmaktan kaçınıyorlar. Daha interaktif ve teknolojik ortamlara ihtiyaç var.”(10ÖK10-)

"Öğrenciler anlamadıkları konularda sıkılıyorlar. Derse adapte olmaları zorlaşıyor. Aslında öğrencilerin yabancı dil öğrenmedeki ihtiyaçları karşılanmıyor diyebiliriz. Öğrenilenler yüzeysel kalıyor bu durumda. Öğrenciyi istekli hale getirmek neredeyse imkansızlaşıyor. Kelime öğretiminde problemler yaşıyoruz. Oysaki dilin en önemli unsuru kelime. Kelime olmazsa olmuyor. Amaç sınav değil de konuşmak için dil öğrenmek. Okulların fiziki ortamı buna göre ayarlansa iyi olur. Materyal eksiğimiz de var.”(12ÖK10+) 


\section{Yabancı Dil Ağırlıklı Programların Ortaokul Düzeyinde Uygulanmasına İlişkin Katılımcı Öğretmen Görüşseri}

Yabancı dil ağırlıklı programların ortaokul düzeyinde uygulanmasına ilişkin katılımcı öğretmen görüşleri analiz edilmiş, 1 tema, olumlu ve olumsuz görüş frekansları oluşturulmuştur. Elde edilen bulgular Tablo 6' da yer almaktadır.

Tablo 6: Yabancı Dil Ağırlıklı Programların Ortaokul Düzeyinde Uygulanmasına İlişkin Katılımcı Öğretmen Görüşleri

\begin{tabular}{lcc}
\hline \multirow{2}{*}{ Tema } & \multicolumn{2}{c}{$\boldsymbol{f}$} \\
\cline { 2 - 3 } & Olumlu Görüş̧ & $\begin{array}{c}\text { Olumsuz } \\
\text { Görüsş }\end{array}$ \\
\hline $\begin{array}{l}\text { Yabancı Dil Ağırlıklı Programların } \\
\text { Ortaokul Düzeyinde Uygulanması }\end{array}$ & 10 & 2 \\
\hline
\end{tabular}

Tablo 6 incelendiğinde, yabancı dil ağırlıklı programların ortaokul düzeyinde uygulanması konusunda katılımcı öğretmenlerin 10'u olumlu görüş belirtirken, 2'si ise olumsuz görüş belirtmiştir.

Yabancı dil ağılıklı programların ortaokul düzeyinde uygulanması konusunda katılıme1 öğretmenler olumlu görüş belirtmekte ve erken yaşta öğrenilen bilgilerin daha kalıcı olacağını dile getirmektedir. Yabancı dil ağıllıklı programların ortaokul düzeyinde uygulanmasına ilişkin katılımcı öğretmen orijinal görüş örnekleri aşağıda verilmiştir:

"Bu programın ortaokul düzeyinde uygulanması çok iyi. 'Ağaç yaş iken eğilir' mantığıyla erken yaşta öğrenilen bilgi daha kolay kalıcı hale gelir. Lisede olsa daha zor öğrenir öğrenciler. 5. Sınıfta öğrettiğimiz bilgileri biz lisede öğrenmiştik. Şuan ki durum daha iyi. Daha erken de olsa öğrenciler bocalar yapamazdı."(5ÖE10+)

"Ilkokul düzeyinde olsa bu program daha faydalı olacağını düşünüyorum. Ortaokul döneminde sınav kaygısı ve iyi bir liseye yerleşme sorunu ortaya çıkıyor."(3ÖE10-)

\section{Yabancı Dil Ağırlıkı Sınıflarda Yaşanan Sorunlara İlişkin Katılımeı Veli Görüșleri}

Yabanc1 dil ağırlıklı sınıflarda öğrencilerin yaşadığı sorunlara ilişkin katılımcı velilerden alınan görüşler analiz edilmiş, 1 tema ve 5 kategori oluşturulmuştur. Elde edilen tema ve kategoriler Tablo 7'de sunulmaktadır.

Tablo 7: Yabancı Dil Ağırlıklı Sınıflarda Yaşanan Sorunlara İlişkin Katılımcı Veli Görüşleri

\begin{tabular}{llc}
\hline Tema & Kategori & $\boldsymbol{f}$ \\
\hline \multirow{3}{*}{ Yabancı Dil Ağırlıklı Sinıflarda } & Fazla Ders Sayısı & 50 \\
Yaşanan Sorunlar & Fazla Ders Saati & 45 \\
& İngilizce Konuşmada Zorluklar & 41 \\
& Fazla Ev Ödevi & 13 \\
& Kullanılan Kaynak Kitap Zorluğu & 8 \\
\hline
\end{tabular}

Tablo 7'ye göre, yabancı dil ağırlıklı sınıflarda öğrencilerin yaşadığı sorunlar konusunda; katılımc1 velilerin 50'si 'fazla ders sayısı' kategorisinde, 45'i 'fazla ders saati' kategorisinde, 41'i 'Ingilizce konuşmada zorluklar' kategorisinde, 13'ü 'fazla ev ödevi' kategorisinde, 8'i ise 'kullanılan kaynak kitap zorluğu' kategorisinde görüş ortaya koymuşlardır.

Katılımcı veliler, programlara ilişkin öğrencilerin yaşadıkları başlıca sorunun fazla ders sayısı olduğunu, genel kültür derslerinin de aynı önemle devam etmesinden dolayı ögrencilerin İngilizceye yeterince zaman ayıramadığını dile getirmektedir. Ek olarak, veliler İngilizce ders saatinin fazla olması nedeniyle öğrencilerin bu yoğunluktan sıkıldığını ifade etmektedir. Velilerin 
en çok vurguladıkları sorunlardan biri de öğrencilerin İngilizce konuşmada zorluk yaşadığıdır. Öğrencilerin konuşmada isteksiz ve çekingen davrandığını, bu konuda programın yetersiz olduğunu ifade etmektedir. Araştırmaya katılan velilerin küçük bir bölümü ise; öğretmenlerin fazla ev ödevi verdiği ve kullanılan kaynak kitabın zor olduğu, bu sebepten öğrencilerin motivasyonlarının düştüğü yönünde görüş bildirmiştir. Yabancı dil ağırlıklı sınıflarda yaşanan sorunlara ilişkin katılımcı veli orijinal görüş örnekleri aşağıda verilmiştir:

\begin{abstract}
"Yabanc1 dil öğrenilirken diğer derslerde ağır bir şekilde devam ettiği için çocuk yeterince İngilizce dersine ağırlı veremiyor. Yabancı dil konuşmada zorlanıyor. Özellikle cümle kurmada zorluk yaşıyor."(59VK)
\end{abstract}

"Yabancı dil dersi fazla olduğu için programları çok ağır oluyor ve çocuklar sıkılıyor. Kendisine ifade edileni anlıyor ama kendisini ifade etmekte sıkıntı yaşıyor.”(10VK)

"Yabancı dil ile ilgilenmeyi sevdiği halde, diğer temel derslerden dolayı istediği zamanı dile ayıramamaktadır. Ev ödevinin fazlalığından da şikayet etmekteyiz.”(29VE)

"5. sinıfta kullanılan kaynak oldukça zordu. Çocuğum bunları yapmakta oldukça zorlandı. Bu da onu 'Başaramayacağım' korkusu içine düşürdü. (47VK)

\title{
8. Yabancı Dil Ağırlıklı Programların Ortaokul Düzeyinde Uygulanmasınaİlişkin Katılımcı Veli Görüşleri
}

Yabancı dil ağırlıklı programların ortaokul düzeyinde uygulanmasına ilişkin katılımcı veli görüşleri analiz edilmiş, 1 tema, olumlu ve olumsuz görüş frekansları oluşturulmuştur. Elde edilen bulgular Tablo 8' de yer almaktadır.

Tablo 8: Yabancı Dil Ağırlıklı Programların Ortaokul Düzeyinde Uygulanmasına İlişkin Katılımcı Veli Görüşleri

\begin{tabular}{lccc}
\hline \multirow{2}{*}{ Tema } & \multicolumn{2}{c}{$f$} \\
\cline { 3 - 4 } & Olumlu Görüş & $\begin{array}{c}\text { Olumsuz } \\
\text { Görüş̧ }\end{array}$ \\
\hline Yabanc1 Dil Ağıllıklı Programların & 68 & 13 \\
Ortaokul Düzeyinde Uygulanması & & \\
\hline
\end{tabular}

Tablo 8 incelendiğinde, yabancı dil ağırlıklı programların ortaokul düzeyinde uygulanması konusunda katılımcı velilerin 68 'i olumlu görüş belirtirken, 13'ünün olumsuz görüş bildirdiği görülmektedir.

Yabancı dil ağırlıklı programların ortaokul düzeyinde uygulanması konusunda katılımcı veliler olumlu görüş ifade etmekte, yabancı dilin erken yaşta daha kolay öğrenildiğini, ilerleyen yaşlarda dil öğrenmenin zorlaştığını öne sürmektedir. Yabancı dil ağırlıklı programların ortaokul düzeyinde uygulanmasına ilişkin katılımcı veli orijinal görüş örnekleri aşağıda verilmiştir:

"Programın ortaokulda uygulanmasını oldukça faydalı buluyorum. Erken yaşta yabancı dil öğrenimi sayesinde çocukların dünyasının genişlediği kanaatindeyim. Kendine güvenen, girişimci, aktif ve araştırmacı bir nesil için gerekli olduğunu düşünüyorum.”(36VK)

"Programın ortaokul düzeyinde uygulanması güzel. Gelişmekte olan çocukların dimağları boş olduğu için daha kolay kavrıyorlar.”(71VE)

“Günümüz dili İngilizce olduğu için en temelden bu dili öğrenmesi şart. Ortaokul bunun için yeterli bir seviye olduğunu düşünüyorum. İlkokul seviyesinde verilmesini çok uygun bulmuyorum. Kendi dilimizi etkin ve doğru kullanması için ilkokulda sadece basit düzeyde İngilizce verilmesini yeterli buluyorum."(15VE

"Bence daha küçük yaşlarda çocuklara öğretilmeli ve bol bol sohbet şeklinde alıştırma yapılmalı. Çünkü çocuklar küçük yaşlarda öğrenme yeteneği daha yüksektir.” (32VK)

\section{Turkish Studies - Educational Sciences}

Volume 14 Issue 6, 2019 


\section{Sonuç ve Tartışma}

Ortaokul düzeyinde yabancı dil ağılıklı programların değerlendirilmesi amacıyla ortaya konulan bu araştırmada durum çalışması modelinden yararlanılmış ve Kırşehir ilinde, yabancı dil ağırlıklı programların uygulandığı ortaokullarda görev yapan yabanc1 dil öğretmenlerinin ve yabancı dil ağırlıklı programların uygulandığı öğrencilerin velilerinin görüşlerine başvurulmuştur. Araştırmanın bulgularına dayalı olarak, yabancı dil ağırlıklı programların öğelerine ilişskin çıkarsamalar Şekil 1'de verilmiştir.

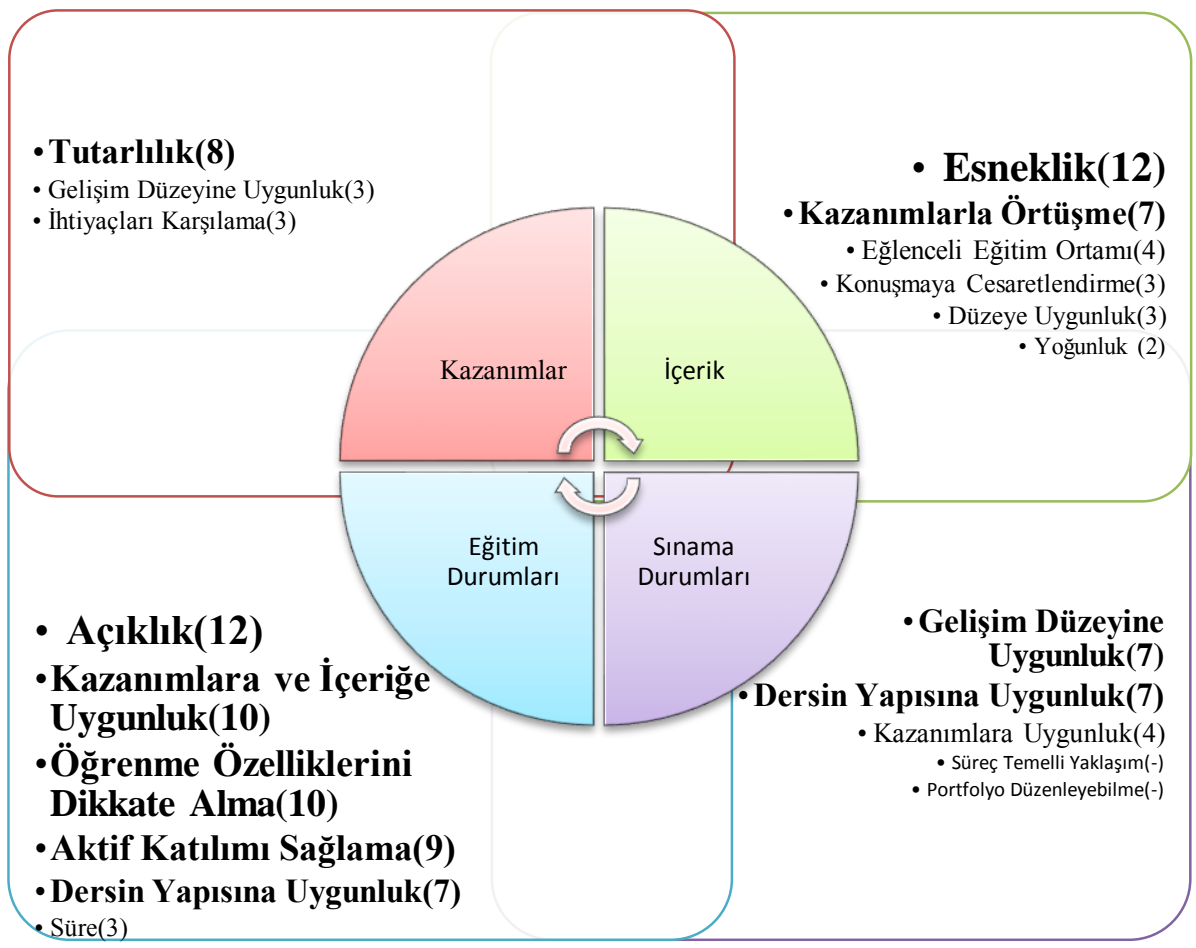

Şekil 1: Yabancı Dil Ağırlıklı Programların Öğelerine İlişkin Çıkarsamalar

Demirel (2000) \& Erden (1998); kazanımı, öğrencilere kazandırılmak istenen beceriler; içeriği, öğrenme-öğretme sürecinde öğrencilere kazandırılacak bilgiler bütünü; eğitim durumlarını, öğrencilere becerileri kazandırmak için hangi öğretim yöntem, teknik ve stratejilerden ve bunları destekleyen öğretim materyallerinden yararlanılacağı; sınama durumlarını ise, öğrencilerin kazanımları edinme derecelerini belirleyen ölçme araçları olarak ifade etmektedir (Büge, 2005).

Araştırmanın Şekil 1'de verilen çıkarsamalarında görüldüğü üzere; katılımcı öğretmenler, yabancı dil ağırlıklı programlarda yer alan kazanımların birbirleriyle tutarlı olduğunu düşünmektedir. Öte yandan kazanımların, öğrencilerin bilişsel ve sosyal gelişim düzeylerine uygun olmadığını ve yabancı dil öğrenimi konusundaki ihtiyaçlarını karşılamadığını ifade etmektedir. Dilekli(2018) tarafından ortaya konulan çalışma da bu araştırma sonuçlarını desteklemekte ve katılımcılar yabancı dil ağırlıklı programlarda yer alan kazanımların sayısının fazla ve öğrencilerin bilişsel seviyesinin üzerinde olduğunu düşünmektedir.

Programların içerik öğesi ele alındığında; katılımcı öğretmenler, bu öğeye ilişkin en belirgin özelliğin esneklik olduğunu, gereken durumlarda değişiklik yapılabildiğini belirtmektedir. Kazanımlarla örtüşmesi konusunda programın içeriğini yeterli bulmakta, ancak eğlenceli bir eğitim ortamı oluşturmada ve öğrenciyi İngilizce konuşmaya cesaretlendirme konusunda içeriğin yetersiz olduğunu dile getirmektedir. Bu durumu, içeriğin öğrenci düzeyinin üzerinde ve çok yoğun olmas1

Turkish Studies - Educational Sciences

Volume 14 Issue 6, 2019 
ile ilişkilendirmektedir. Aydın ve Zengin(2008) çalışmalarında kaygının dil öğrenimindeki olumsuz etkisini incelemişlerdir. Yabancı dil öğrencilerinin yeterlilik düzeyleri, öğrencilerin dildeki yetenek düzeyleri, sınav uygulamaları ve yabancı dil derslerinin zorluk düzeyi gibi unsurların, öğrencilerde kaygıya sebep olduğunu ve kaygının ortadan kaldırılması ya da iyi yönlendirilmesiyle dil ediniminin gerçekleşeceğini ve öğrenmede başarının artırılacağını savunmuşlardır.

Ek olarak, katılımcı öğretmenler programlarda etkinliklerin, yöntem ve tekniklerin açık ve net bir şekilde ortaya konulduğunu belirtmekte, kazanımlara ve içeriğe uygunluğu ve öğrencilerin öğrenme özellikleri dikkate alınarak oluşturulduğu konusunda olumlu görüş ifade etmektedir. Etkinliklerin aktif katılımı sağladığı ve yöntem-tekniklerin İngilizce dersinin yapısına uygun olduğu görüşündedir. Fakat programlarda önerilen sürenin yetersiz olduğu ve sıkıntı yaşandığı, müfredatı tamamlama çabasındayken, konuşma ve dinleme etkinliklerine yeterince zaman ayrılamadığını dile getirmektedir.

Programların değerlendirme boyutuna ilişkin katılımcı öğretmenler, ölçme değerlendirme tekniklerinin öğrencilerin yabancı dil öğrenmedeki gelişim düzeyleri ve dersin yapısı dikkate alınarak belirlendiği yönünde görüş belirtmekteyken, önerilen ölçme değerlendirme etkinlikleri ile programlarda yer alan kazanımların ölçülebilir fakat kesinlikle yetersiz olduğunu düşünmektedir. Ayrıca değerlendirmenin sonuç odaklı yaklaşımla yapıldığını, portfolyo değerlendirme konusunda da öğrencilerin yetersiz olduğunu ifade etmektedir. Büge (2005), Türkiye İngilizce Öğretim Programı ve Finlandiya Yabancı Dil Programı'nı karşılaştırmalı olarak incelediği çalışmasında; Türkiye İngilizce Öğretim Programı'nda yer alan sınama durumu örneklerini yetersiz bulmuş ve dört dil becerisini kapsamadığı sonucuna ulaşmıştır.

Programlara ilişkin görüşleri alındığında; katılımcı öğretmenler yaşadıkları en önemli sorunun yetersiz süre ve yoğun program olduğunu, konuşma ve dinleme etkinliklerine yeterince zaman ayrılamadığını dile getirmektedir. Öğrencilerin yabancı dil öğrenimi konusundaki ihtiyaçlarını karşılamak noktasında da programın yetersiz kaldığını, öğrencilerin İngilizce konuşmak konusunda isteksiz davrandığını ve motivasyon sorunu yaşandığını ifade etmektedir. Gardner ve Lambert(1972) ve Kennedy(1996), yabanc1 dil öğreniminde motivasyonu konu alan çalışmalarında, motivasyon ve başarı arasında anlamlı bir korelasyon elde etmişlerdir. Acat ve Demiral(2002) ise çalışmalarında, yabancı dil öğrenimindeki sorunun motivasyon eksikliğinden kaynaklandığını öne sürmüşlerdir. Ek olarak materyal ve kaynak eksikliği nedeniyle program etkili ve verimli şekilde uygulanamamakta ve öğrenilmesi gereken kelimelerin oldukça yoğun olması sebebiyle öğretmenler kelime öğretiminde zorluklar yaşamakta, öğrenciler de bu konuda isteksiz davranmaktadır.

Yabancı dil ağılıklı programların ortaokul düzeyinde uygulanması konusunda görüşlerine başvurulduğunda ise, katılımcı öğretmenler bu uygulamayı olumlu olarak değerlendirmekte ve erken yaşta öğrenilen bilgilerin daha kalıcı olacağını dile getirmektedir. Doye ve Lüttge(1977) yapmış olduğu çalışmada, yabancı dil eğitimine erken yaşta başlayan öğrencilerin başarı durumlarının, daha sonra başlayan öğrencilerden daha ileri düzeyde olduğu sonucuna ulaşmıştır. Grobner(1995), çocuklardaki taklit yeteneğinin kuvvetli olmasını, yabancı dilde telaffuz ve vurgu açısından önemli bir katkı olarak görmekte ve erken yaşta yabancı dil eğitimi ile çocukların bu yeteneğinden faydalanabileceğini dile getirmektedir. Haznedar(2010) ise çalışmasında, yabancı dil eğitiminde en güzel adımın 1997 yılından bu yana benimsenen erken yaşta yabancı dil öğretimi politikası olduğunu ve bu uygulamanın son yıllarda başta Avrupa Birliği üyesi ülkeler olmak üzere geniş bir coğrafyada ciddi bir biçimde tartışıla gelen bir olgu olduğunu vurgulamaktadır. Ayrıca Dilekli(2018) de ortaya koymuş olduğu araştırmada, yabancı dil ağırlıklı programın 5. Sınıf düzeyinde uygulanması konusunu ele almakta ve katılımcılar bu uygulamayı olumlu bir gelişme olarak değerlendirmektedir. 
Yabancı dil ağırlıklı programların uygulanması sırasında yaşanan sorunlara ilişkin sonuçlar Şekil 2' de görülmektedir.

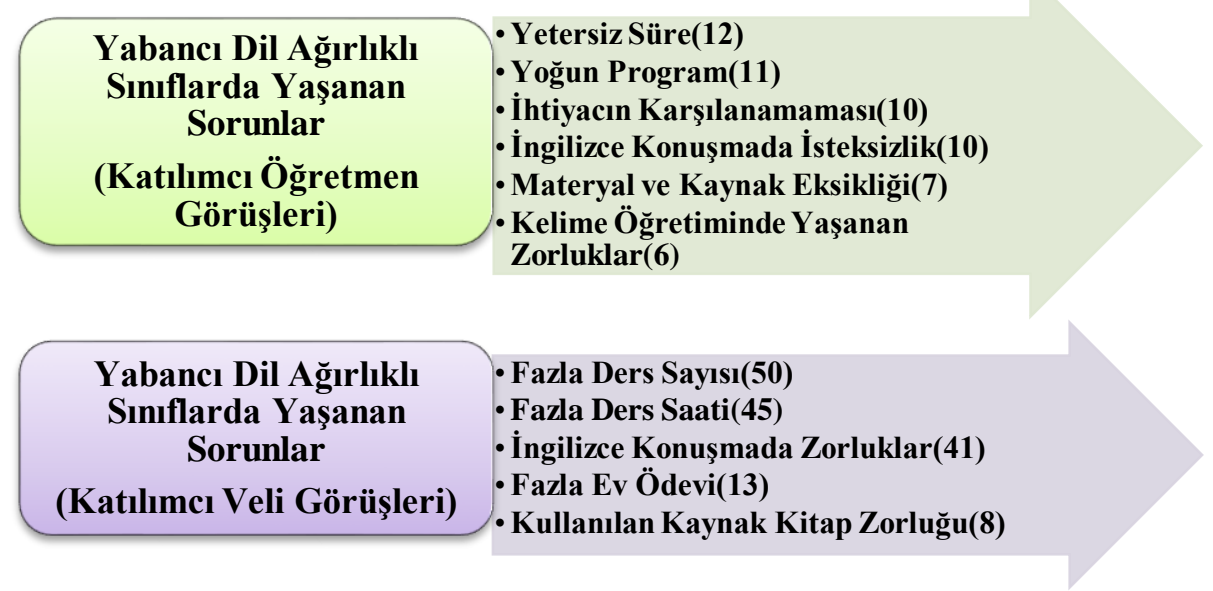

Şekil 2: Yabancı Dil Ağırlıklı Sınıflarda Yaşanan Sorunlara İlişkin Çıkarsamalar

Şekil 2'de görüldüğ̈̈ üzere; yabancı dil ağırlıklı sınıflarda eğitim gören öğrencilerin velileri, programlara ilişkin öğrencilerin yaşadıkları başlıca sorunun fazla ders sayısı olduğunu belirtmektedir. Genel kültür derslerinin de aynı önemle devam etmesinden dolayı öğrencilerin İngilizceye yeterince zaman ayıramadığını ve İngilizce ders saatinin fazla olması nedeniyle öğrencilerin bu yoğunluktan sıkıldığını ifade etmektedir. Özçakır(2015)'a göre; önemli olan, yabancı dil ders programlarının değiştirilmesi değil, yabancı dil ders saatinin haftalık gerektiği kadar artırılmasıdır. Velilerin en çok vurguladıkları sorunlardan biri de öğrencilerin İngilizce konuşmada zorluk yaşadığı, isteksiz ve çekingen davrandığıdır. Araştırmaya katılan velilerin birkaçı ise; öğretmenlerin fazla ev ödevi verdiği ve kullanılan kaynak kitabın zor olduğu yönünde görüş bildirmiştir.

Ayrıca veliler, bu programların ortaokul düzeyinde uygulanmasının olumlu bir gelişme olduğunu ifade etmekte, yabancı dilin erken yaşta daha kolay öğrenildiğini, öne sürmektedir.

\section{Öneriler}

- Programlarda yer alan kazanımlar, öğrencilerin bilişsel düzeylerine göre yeniden ele alınabilir. Bireylerin hedef dilde iletişim becerilerini geliştirecek kazanımlara yer verilebilir.

- İçeriğin amaç değil, dili iyi kullanmak için araç olması ilkesiyle içerikteki yoğunluk azaltılabilir ve önerilen sürenin yeniden gözden geçirilmesinin yararlı olacağı söylenebilir.

- Yabancı dil ağırlıklı sınıflarda ders yoğunluğu azaltılabilir.

- Sonuç odaklı değerlendirme yaklaşımına alternatif olarak, portfolyo değerlendirme, proje ve performans değerlendirme gibi sürece dönük teknikler de ișe koşulabilir.

\section{KAYNAKÇA}

Acat, B. \& Demiral, S. (2002). Türkiye'de yabancı dil öğreniminde motivasyonkaynakları ve sorunlar1. Kuram ve Uygulamada Eğitim Yönetimi, 31, 312-329.

Akerson - Erkman, F. (2008). Dile genel bir bakış. İstanbul: Multilingual.

Aydın, S. ve Zengin, B. (2008). Yabancı dil öğreniminde kaygı: Bir literatürözeti. Journal of Language andLinguisticStudies, Vol. 4, No. 1. 
Bağçeci, B. (2004). Ortäğretim kurumlarında Ingilizce öğretimine ilişkin öğrenci tutumları (Gaziantep ili örneği), XIII. Ulusal Eğitim Bilimleri Kurultayı Bildiri Özetleri, İnönü Üniversitesi Eğitim Fakültesi. Ankara: Öncü Basım Evi.

Başkan, Ö. (2006). Yabancı dil öğretimi ilkeler ve çözümler. İstanbul: Multilingual Yabancı Dil Yayınları.

Büge, B. C. (2005). Türkiye ilköğretim Ingilizce öğretim programı ve Finlandiya yabancı dil programının karşılaş̧tıılmalı olarak incelenmesi. Yüksek Lisans Tezi, Hacettepe Üniversitesi Sosyal Bilimler Enstitüsü, Ankara.

Dilekli, Y. (2018). Ortaokul İngilizce hazırlık sınıfı programı pilot uygulamasının öğretmen görüşlerine göre değerlendirilmesi.Uluslararası Toplum Araştırmaları DergisiInternational Journal of SocietyResearches, Vol. 8, No. 15.

Doye, P. \&Luttge, D. (1977). Untersuchungen zum Englischunterricht in der grundschule. Bulunduğu Eser: H, Sauer. (1993). Fremdsprachlicherfruhbeginn in der diskussion. NeusprachlicheMitteilungenausWissenschaftundPraxis, 2, 85-93.

Gardner, R. C. \& Lambert, W. E. (1972). Attitudesandmotivation in secondlanguagelearning. Newbury House, Rowley, MA.

Grobner, W. (1995). Schulversuch "Lebenderfremdsprachen in der grundschule." erziehungundunterricht. OsterreichischePadagogischeZeitschrift, Vol. 2, No. 3. 203-209.

Haznedar, B. (2010). Türkiye'de yabancı dil eğitimi: Reformlar, yönelimler ve öğretmenlerimiz. ICONTE International Conference on New Trends in EducationandTheirImplications. 1113 November, 2010, Antalya-Turkey.

Kennedy, J. R. (1996). Variations in themotivation of successfulandunsuccessfulTurkishlearners of English.Unpublished MA Thesis. BogaziçiUniversityInstitute of SocialSciences, Istanbul.

Köse, E. (2013). Bilimsel araştırma modelleri. R. Y. Kıncal, (Ed.), Bilimsel araştırma yöntemleri. Ankara: Nobel Akademik Yayınc1lik, 2. Basım.

Kuzu, H. (2013). Ortaöğretimde yabancı dil (Almanca) ögretiminin öğrenci memnuniyeti açısından değerlendirilmesi: Anadolu lisesi örneği. Yüksek Lisans Tezi, Selçuk Üniversitesi Sosyal Bilimler Enstitüsü, Konya.

Oğuzkan, F. (1993). Eğitim terimleri sözlüğ̈̈. Ankara: Emel Matbaacılık.

Özçakır, A. İ. (2015). Ah, bu “İngilizce dersleri’! Erişim tarihi: 25 Mayıs 2019,http://blog.milliyet.com.tr/ah--bu--ingilizce-dersleri /Blog/?BlogNo=489745

Pöhnl, K. (2010). Differenzieren im sprachunterrichtDeutschalsfremd/zweitsprache, Diplomarbeit, Universität Wien.

Ruck, H. (1992). Französisch in der grundschule-einwissenschaftlichbegleiteterschulversuch in Rheinland-Pfalz. Bulunduğu Eser: G. Gompf (Ed.) fremdsprachenbeginn ab klasse 3: LernenfürEuropa. Cornelsen, Berlin.

Sertdemir, M. (2013). Türkiye'de ortä̈ğretimde yabancı dil öğretiminde görselliğin yeri. Yüksek Lisans Tezi, Frrat Üniversitesi Sosyal Bilimler Enstitüsü, Elazığ.

Tarakçıŏlu, A. Ö. (2012). Yabancı dil ögretiminde materyal geliştirme, materyal uyarlama ve materyal kullanımın önemi. A. Sarıçoban ve Z. M. Tavil, (Ed.), Yabancı Dil Öğretiminde Öğretim Teknolojileri ve Materyal Tasarımı (1-18). Ankara: Anı Yayıncılık.

Tepav\& British Council (2013). Türkiye' deki devlet okullarında İngilizce dilinin öğretimine ilişkin ulusal ihtiyaç analizi. Ankara. 